\title{
A hybrid systems biology and systems pharmacology investigation of Zingerone's effects on reconstructed human epidermal tissues
}

\author{
Elham Amjad ${ }^{\dagger}$, Babak Sokouti $^{* \dagger}$ and Solmaz Asnaashari ${ }^{*}$
}

\begin{abstract}
Background: As individuals live longer, elderly populations can be expected to face issues. This pattern urges researchers to investigate the aging concept further to produce successful anti-aging agents. In the current study, the effects of Zingerone (a natural compound) on epidermal tissues were analyzed using a bioinformatics approach.

Methods: For this purpose, we chose the GEO dataset GSE133338 to carry out the systems biology and systems pharmacology approaches, ranging from identifying the differentially expressed genes to analyzing the gene ontology, determining similar structures of Zingerone and their features (i.e., anti-oxidant, anti-inflammatory, and skin disorders), constructing the gene-chemicals network, analyzing gene-disease relationships, and validating significant genes through the evidence presented in the literature.

Results: The post-processing of the microarray dataset identified thirteen essential genes among control and Zingerone-treated samples. The procedure revealed various structurally similar chemical and herbal compounds with possible skin-related effects. Additionally, we studied the relationships of differentially expressed genes with skinrelated diseases and validated their direct connections with skin disorders the evidence available in the literature. Also, the analysis of the microarray profiling dataset revealed the critical role of interleukins as a part of the cytokines family on skin aging progress.

Conclusions: Zingerone, and potentially any constituents of Zingerone (e.g., their similar compound scan functionality), can be used as therapeutic agents in managing skin disorders such as skin aging. However, the beneficial effects of Zingerone should be assessed in other models (i.e., human or animal) in future studies.
\end{abstract}

Keywords: Zingerone, Skin-aging, Systems biology, Systems pharmacology, Interleukin, Gene-disease association, Gene-chemicals network, Similar compounds, Skin disorder

\section{Background}

The skin, consisting of the epidermis, dermis, and subcutaneous layers, is the body's largest organ and forms a physical barrier between the external environment and

\footnotetext{
*Correspondence: b.sokouti@gmail.com; asnaasharisolmaz@gmail.com tElham Amjad and Babak Sokouti contributed equally to this research and should be regarded as joint first author

Biotechnology Research Center, Tabriz University of Medical Sciences, Tabriz, Iran
}

the internal environment that protects and maintains. As the population ages, the epidermis and dermis are the primary targets for various changes that encourage the development of novel anti-aging therapeutic agents [1]. Physical and chemical environmental factors such as UV radiation and xenobiotics play significant roles in the oxidative stress of skin cells by altering the involved signaling pathways, immunosuppression, and producing reactive oxygen species (ROS) and photosensitivity 
diseases [2]. Various skin anti-aging treatment procedures are available, including topical retinoids, peels (e.g., salicylic acid), botulinum neurotoxin, soft tissue fillers, collagens, hyaluronic acid, autologous fat, allogenic and synthetic products, lasers, surgical procedures, and endocrinological therapies, as well as other alternatives such as phytohormones [3]. The reports showed that the use of natural compounds has promising results in reducing UV-induced effects of skin aging, which have made them play the primary role in cosmetic-related sciences [4].

Zingerone (4-(4-hydroxy-3-methoxyphenyl)-2-butanone) is an inexpensive and nontoxic phenolic alkanone structure derived from Ginger (Zingiber officinale Rosc.), which is a widely used herb in pharmaceutical and food industries throughout the world (e.g., China, Greece, and India) [5-7]. Zingerone is a result of gingerol dehydration while being cooked or dried [5]. The main pharmacological properties of Zingerone include anti-oxidative, immune-stimulant, anti-inflammatory, and anti-cancer effects [8]. Previous studies reported the anti-ultraviolet $B(U V B)$ radiation activity of Zingerone in protecting the epidermis [9].

Zingerone likely acts as a neuroprotective agent by blocking the apoptotic pathway, thus preventing oxidative stress and limiting inflammation [10]. It is thought that polyphenolic compounds called Zingerone are present in ginger and have potent anti-oxidant properties, exhibit free radical scavenging activity, and provide resistance to oxidative stress [11]. Various protective effects of Zingerone have been reported in lead-induced toxicity [12], streptozotocin/high fat diet-induced type 2 diabetes [13], rheumatoid arthritis [14], lipopolysaccharide-induced oxidative stress, DNA damage, cytokine storms [15], experimental colon carcinogenesis [16], alloxan-induced oxidative stress [17], cyclophosphamide-induced organ toxicity [11], and cisplatin (cis-diamminedichloroplatinum (II))-induced jejunal toxicity [18]. Zingerone substantially decreased NF- $\kappa$ B, TGF- $\beta$, TNF- $\alpha$, IL-1 $1 \beta$, IL-6, and Hs-CRP levels while considerably increasing IL-10 levels and restoring anti-oxidant enzyme levels [14]. Thus, when given to animals (e.g., Wistar rats) exposed to the above-mentioned toxicities and diseases, Zingerone may reduce oxidative stress, inflammation, and multiorgan damage.

To the best of the authors' knowledge, no investigation has used systems biology and systems pharmacology approaches to determine significantly differentially expressed genes between control tissues and those treated by Zingerone. In this study, we used the available microarray gene expression profiling datasets to meet this aim. The functional and cellular mechanisms of identified genes were also inspected. Then, various network analyses, including gene-disease and gene-chemicals, were performed. Finally, the effects of chemical and herbal compounds similar to Zingerone's structure were studied in detail, and the validation of potential significant genes was reviewed based on evidence found in the literature.

\section{Methods}

A summary of the current research workflow is illustrated as a flowchart diagram, as shown in Fig. 1.

\section{Data source}

The dataset used in this study is publicly available from the gene expression omnibus (GEO) database repository of the national center for biotechnology information (NCBI) (i.e., https://www.ncbi.nlm.nih.gov/geo/) with the GPL17692 [HuGene-2_1-st] Affymetrix Human Gene 2.1 ST Array [transcript (gene) version] platform. The only available GEO dataset, GSE133338, included six reconstructed human epidermal (RHE) tissues treated by Zingerone $(n=3)$ and water control $(n=3)$, as shown in Fig. 1.

\section{Differentially expressed genes (DEGs) between two types of tissues}

Dr. Richard Simon and the BRB-ArrayTools Development Team developed a genomics analytical tool, BRBArrayTools (v4.6.1, stable version), to determine potent DEGs. Several steps, including GEO dataset import, gene filtering (i.e., $\mid$ fold change $\mid \geq 1$ ), and normalization (i.e., quantile normalization), and annotation (i.e., "pd. hugene.2.1.st" $R$ package [19]), were required to identify the significant DEGs. The BRB-ArrayTools used the gcrma (guanine-cytosine robust multi-array analysis) algorithm to map the probe intensities into their corresponding gene expression values by discarding existing noise. The comparison between two treated groups resulted in the identification of significant DEGs using values of 10,000 and 1 for univariate permutation tests and the threshold of fold change. The obtained DEG results were significant at $p \leq 0.05$.

\section{Gene ontology and functional enrichment analyses}

DAVID v. 6.8 (Database for Annotation, Visualization, and Integrated Discovery), which is freely available at http://david.abcc.ncifcrf.gov/summary.jsp, provided the evaluation of the gene ontology (GO). This evaluation included cellular components, molecular functions, and biological processes of DEGs [20, 21]. The threshold for the EASE score of a modified Fisher exact $p$ value was set to its default value of 0.1 . 


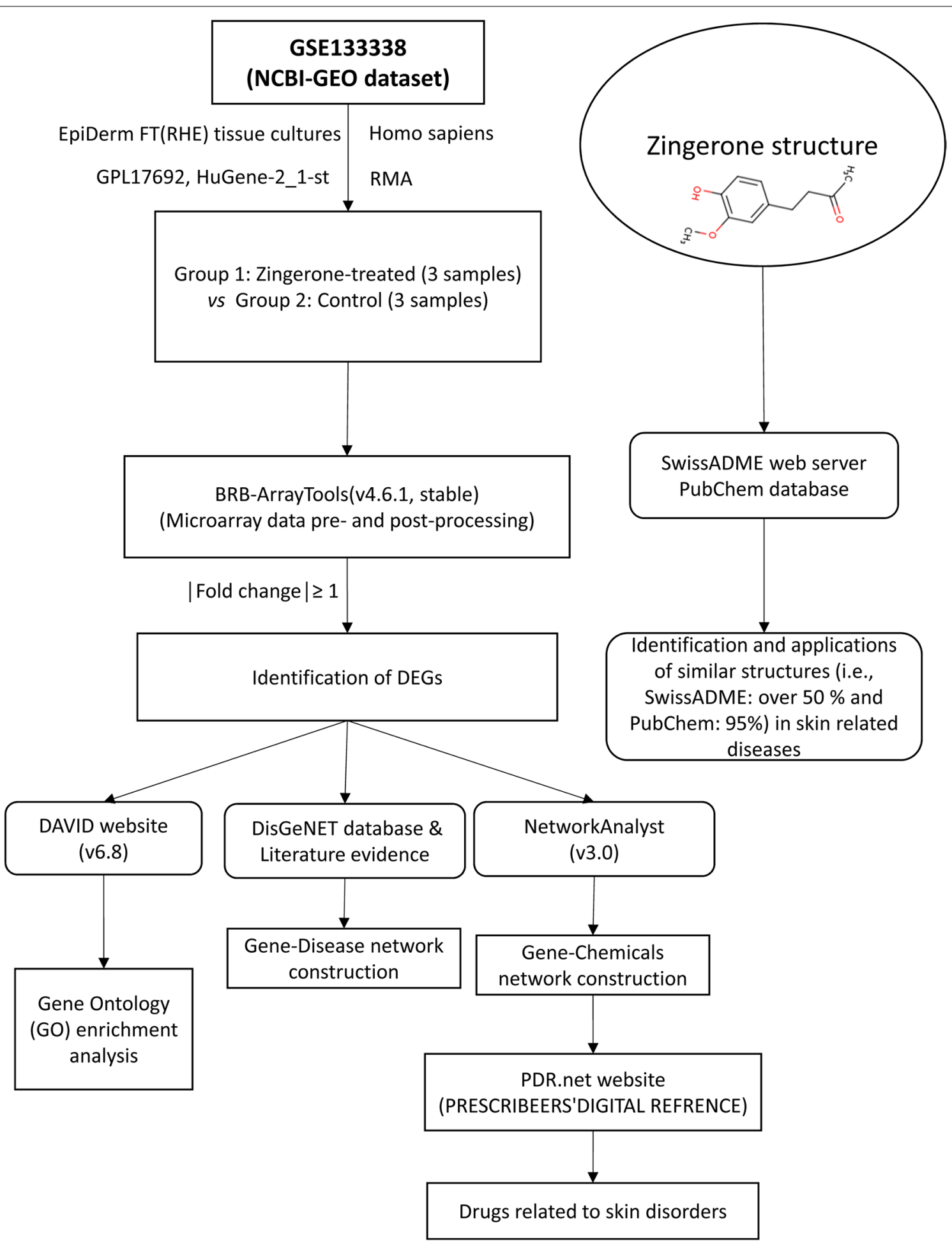

Fig. 1 The overall workflow of the systems biology and systems pharmacology approaches

\section{Effectiveness and similarity structure analyses}

\section{of Zingerone}

The canonical SMILES (simplified molecular-input lineentry system) string for Zingerone structure (shown in Fig. 2a) was obtained from the PubChem compound database (https://pubchem.ncbi.nlm.nih.gov/compound) [22]. Each string of SMILES was used for PubChem similarity structure and ADME prediction using online web 


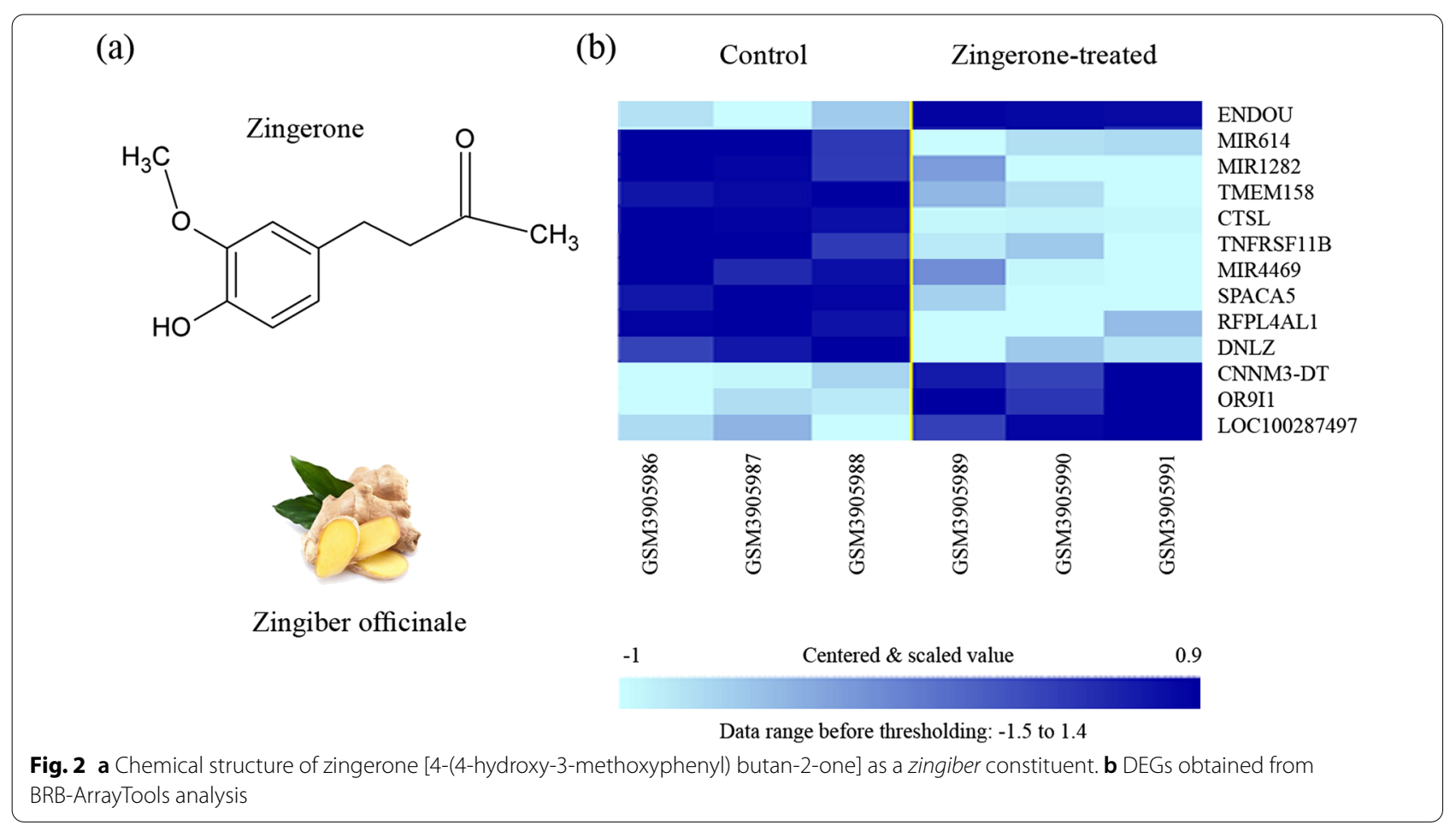

server tools, i.e., SwissADME [23-25], SwissSimilarity [26], and SwissTargetPrediction [27]. The SwissADME web server covers the drug design and discovery by computing several parameters, including physicochemical descriptors, ADME-related parameters, pharmacokinetic properties, drug-likeness effect, and studying medicinal chemistry friendliness of SMILES structure.

The similarity criteria for the PubChem similarity structure and the SwissSimilarity tools were 0.92 and 0.50 , respectively. Finally, we screened the literature for any existing evidence for functionalities of similar compounds.

\section{Gene-disease and gene-chemicals network analyses}

We extracted the related diseases with evidence according to the significant genes obtained through the userfriendly DisGeNET (i.e., http://www.disgenet.org/) platform, derived from the literature on human genedisease associations [28]. Additionally, the involvement of obtained DEGs affected by Zingerone treatment in several specific diseases (and possibly in skin-related disorders) was thoroughly screened through the literature studies to confirm and validate whether such genes are expressed as potential biomarkers of the disease. Furthermore, we constructed and analyzed the gene-chemicals network from the NetworkAnalyst 3.0 webserver to reveal potent associations between genes and compounds available in literature [29].

\section{Results}

Since missing any possible genes could affect the final results, all of the genes included in the microarray dataset are considered. The data preprocessing and class comparison approach using a two-sample $t$ test revealed a total of sixty probe IDs, from which only thirteen DEGs were available as annotated genes. Four genes were downregulated, and nine were upregulated (as shown in Fig. 2b), along with their gene expression levels between control and Zingerone-treated samples.

The DAVID functional annotation tool revealed that two cellular components (i.e., (i) GO:0005615, and extracellular space with four involved genes TNFRSF11B, CTSL, ENDOU, and SPACA5 and (ii) GO:0005576, an extracellular region with three involved genes TNFRSF11B, CTSL, and ENDOU) were found significant. The kappa values of 1.00 and 0.80 indicated a very high level of similarity between the two GO terms. Moreover, the statistical measurement values for GO:0005615 and GO:0005576 were fold enrichments of 7.73 and 4.85, Bonferroni values of 0.09 and 0.72 , Benjamini values of 0.088 and 0.60 , and false discovery rate (FDR) values of 0.088 and 0.6 , respectively. The detailed inspection of GO terms shows that their corresponding child terms have various relationships and cross-references with GO:0005576 and GO:0005615.

The relationships involving the extracellular space suggest that interleukin-35 complex, interleukin-27, interleukin-23, 
and interleukin-12 were part of GO:0005615. Moreover, the relationships involving the extracellular region were mainly part of the extracellular isoamylase complex, extracellular ferritin complex, extracellular space, extracellular vesicle, and extracellular matrix, to mention a few.

Four types of interleukins (i.e., interleukin-1, interleukin-6, interleukin-34, and interleukin-34 alpha) had direct relationships with cross-references of GO:0005615 (for more information, refer to https://www.ebi.ac.uk/ QuickGO/GTerm?id=GO:0005615). Several interleukin types, including interleukin-12 alpha, interleukin-23 alpha, interleukin-17, interleukin-1 alpha, interleukin-1 beta, and interleukin-6, were related to cross-references of GO:0005576 (derived from https://www.ebi.ac.uk/ QuickGO/GTerm?id=GO:0005576).

The assessment of the absorption, distribution, metabolism, and excretion (ADME) of the Zingerone structure using the bioavailability radar (Fig. 3a) indicates the high bioactive drug-likeness property and represents the lipophilicity, molecular weight, solubility, and flexibility properties positioned in the pink area. Moreover, physicochemical and lipophilicity properties (Lipinski's rule of five) (i.e., molecular weight: $194.23 \mathrm{~g} / \mathrm{mol}$, number of rotatable bonds: 4 , number of $\mathrm{H}$-bond acceptors: 3, number of $\mathrm{H}$-bond donors: 1 , and consensus Log Po/w: 1.79) show no violations. The water solubility parameters, including $\log \mathrm{S}$ (ESOL), Log S (Ali), and Log S (SILICOS-IT), demonstrate very soluble, very soluble, and soluble features, respectively. Also, the pharmacokinetics properties reveal a high level of gastrointestinal absorption and only CYP1A2 inhibitory function among other cytochrome enzymes inhibitors.
The SwissTargetPrediction analysis results in a total of 100 target proteins for Zingerone, among which enzymes, secreted proteins, nuclear receptors, and oxidoreductases make up the highest percentages (Fig. 3b). A further inspection of similar structures through the SwissSimilarity and PubChem uncovered two FDA-approved drugs (i.e., Nabumetone and Masoprocol), two experimental drugs (i.e., Matairesinol and 3-(4-hydroxyphenyl)-1-(2,4,6-trihydroxyphenyl)propane1-one), and three Zingiber constituents (i.e., 6-Shogaol, 6-Paradol, and 6-Gingerol) (listed in Table 1). The inspection also revealed their validated anti-inflammatory and anti-oxidant properties, as well as the confirmed skin disorders, such as skin anti-aging, through the evidence provided in the literature.

The gene-disease relationship outcomes from the DisGeNET (accompanied by the relevant evidence from the literature) are summarized in Table 2 . The results indicate that the DEGs influence various diseases, including skin-related disorders. Furthermore, the construction of the gene-chemicals network shows the involvement of seven DEGs that are directly associated with different chemicals. Only four of them (i.e., TNFRSF11B, DNLZ, OR9I1, and MIR614) are related to twenty-three skinrelated compounds (shown in Fig. 4).

\section{Discussion}

Sunlight is a source of ultraviolet (UV) radiation, which can harm the skin. Skin aging, which results from exposure to UV radiation, is often classified into three major categories (i.e., UV-A, UV-B, and UV-C). UV-A makes up $95 \%$ of the UV rays that reach the Earth's surface, and

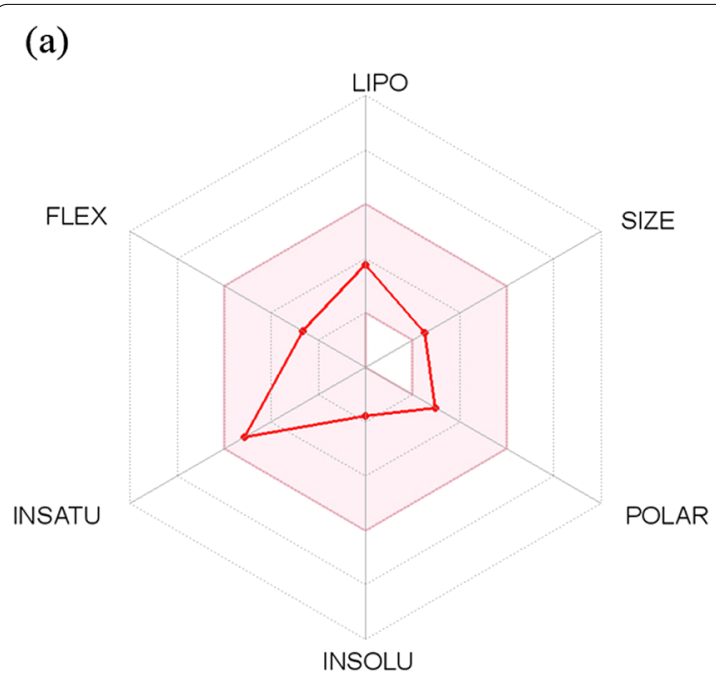

(b)

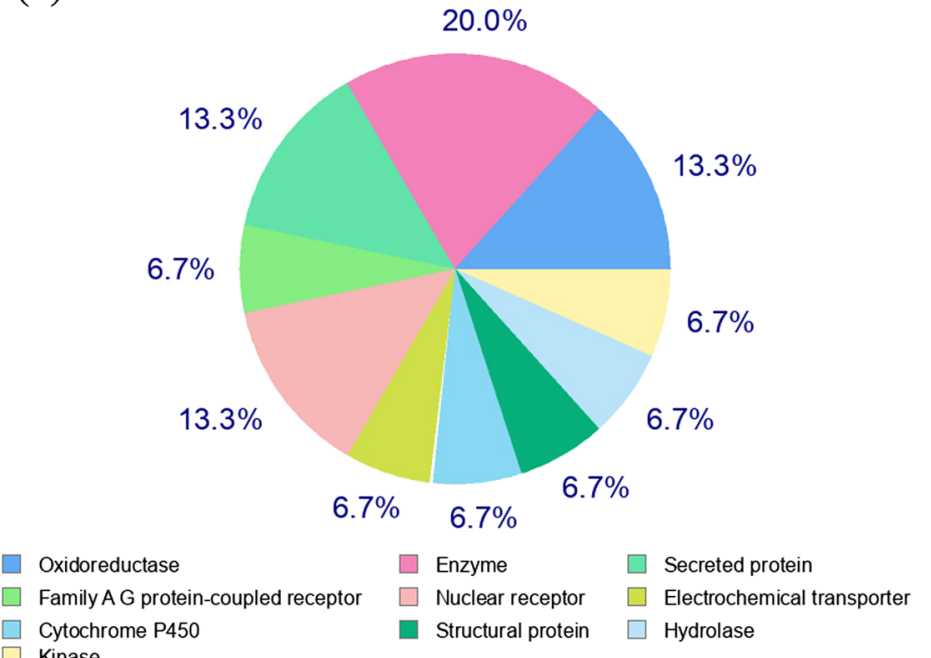

Fig. 3 a The bioavailability radar chart of zingerone structure obtained from SwissADME prediction, $\mathbf{b}$ the small molecule protein targets for zingerone structure obtained from SwissTargetPrediction web server 
Table 1 The list of identified compounds from SwissSimilarity and PubChem structure similarity accompanied by their anti-oxidant, anti-inflammatory, and related skin disorders

\begin{tabular}{|c|c|c|c|c|c|c|}
\hline Item & Compound & Similarity & Status & Antioxidant & Anti-inflammatory & Skin disorders \\
\hline 1 & Nabumetone & $0.8^{1}$ & FDA approved & $\nabla[62]$ & $\nabla[63]$ & Skin injury [64] \\
\hline 2 & Masoprocol & $0.672^{1}$ & FDA approved & $\nabla[65]$ & $\nabla[65]$ & Sun damage (actinic keratosis) [66] \\
\hline 3 & Matairesinol & $0.815^{2}$ & Experimental & $\nabla[67]$ & $\nabla[68]$ & Skin aging [69] \\
\hline 4 & $\begin{array}{l}\text { 3-(4-hydroxyphenyl)-1-(2,4,6- } \\
\text { trihydroxyphenyl)propan-1-one } \\
\text { (Phloretin) }\end{array}$ & $0.726^{2}$ & Experimental & $\square[70]$ & $\nabla[70]$ & Skin damage $[71,72]$ \\
\hline 5 & 6-Shogaol & $>0.95^{3}$ & Zingiber constituents & $\nabla[73,74]$ & $\nabla[73,74]$ & Skin aging [75] \\
\hline 6 & 6-Paradol & $>0.95^{3}$ & Zingiber constituents & $\nabla[76,77]$ & $\nabla[77]$ & Skin cancer [76] \\
\hline 7 & 6-Gingerol & $>0.92^{3}$ & Zingiber constituents & $\nabla[74]$ & $\nabla[74]$ & Skin aging and damage $[75,78]$ \\
\hline
\end{tabular}

${ }^{1}$ The obtained results are from SwissSimilarity through performing ligand-based virtual screening of combined FDA approved drugs $(\mathrm{n}=1516)$ of small molecules $(>50 \%)$

${ }^{2}$ The obtained results are from SwissSimilarity through performing ligand-based virtual screening of combined experimental drugs ( $\mathrm{n}=4788$ ) of small molecules $(>50 \%)$

${ }^{3}$ The obtained results are from PubChem structure similarity through Tanimoto threshold of $95 \%$ and $92 \%$

UV-B makes up the remaining 5\% [30]. UV-C is absorbed by the ozone layer. Because of the small amount of UV-B that reaches the Earth, there is no substantial evidence, confirming that UV-B causes more damage than UV-A. UV-A and UV-B may both harm the DNA and proteins of cells [31, 32]. UV light causes reactive oxygen species (ROS) through oxidized lipids and proteins to be produced on the skin's surface. These ROS initiate oxidative stress and mutations, thus accelerating skin aging and wrinkling. UV-A primarily promotes the production of ${ }^{1} \mathrm{O}_{2}$, whereas both UV-A and UV-B cause the production of $\mathrm{O}_{2}{ }^{-}$via the activation of NADPH oxidase [33-35]. Exposure to UV-B radiation induces erythema by upregulating the expression of cyclooxygenase-2 (COX-2), which stimulates the inflammation process [36].

As we age, we naturally produce less collagen and other skin components, resulting in reduced collagen synthesis and enhanced collagen breakdown. This causes the appearance of skin aging associated explicitly with dermal matrix alterations that may include wrinkling, stiffness, and weakness of skin aging, as well as loss of skin elasticity [37]. Through the release of interleukins (e.g., (IL)-1a and IL-6), the ${ }^{1} \mathrm{O}_{2}$ produced by UV-A promotes matrix metalloproteinase (MMP-1) generation in human skin fibroblasts [38, 39] and decreases collagen synthesis [40].

The effects of several anti-oxidants on the skin and skin cells, including ascorbic acid, tocopherols, carotenoids, natural compounds, and polyphenols, are of great importance [41]. These chemicals are mainly responsible for ROS and DNA damage reduction generated on the skin's surface. Among these, polyphenols are a kind of molecular structure generally extracted from plants with the structural feature of phenol units with anti-inflammatory and anti-oxidant properties. They are reported to have
COX inhibition activity, promote resistance to oxidative stress, and stop skin aging [42]. Moreover, the anti-oxidant or anti-inflammatory activities of phenolic acids can be enhanced through the presence of methoxy $\left(-\mathrm{OCH}_{3}\right)$, phenolic hydroxyl (-OH) groups, and carboxylic acid ($\mathrm{CH}_{2} \mathrm{COOH},-\mathrm{CH}=\mathrm{CHCOOH},-\mathrm{COOH}$ ) [43].

To investigate the anti-oxidant activity of the compounds, $\mathrm{IC}_{50}$ values are quantitatively measured to indicate how much of a particular inhibitory chemical is used to inhibit a biological component, such as an enzyme or receptor, by fifty percent. The higher antioxidant activities are in direct relationship with smaller $\mathrm{IC}_{50}$ values [43]. As listed in Table 3, the structures of Zingerone and similar compounds obtained from the results represent FDA-approved/experimental drugs and natural compounds. These chemicals with phenolic hydroxyl or methoxy groups automatically inherit the anti-oxidant and anti-inflammatory activities that prevent skin aging. On the other hand, their $\mathrm{IC}_{50}$ values were extracted from bindingdb.org, a public database of measured binding affinities [44, 45]. The extracted $\mathrm{pIC}_{50}=-\mathrm{LOG}_{10}\left(\mathrm{IC}_{50}\right)$ values for eight structurally similar compounds and Zingerone range from 3.8 to 4.5 in different target/enzyme environments, representing their high anti-oxidant and anti-inflammatory activities. The primary mechanism of action of these compounds in terms of their anti-oxidant features is the direct scavenging of free radicals. The radical oxidation of anti-oxidants results in a more stable, less radical reaction. By interacting with the reactive radicals, anti-oxidants stabilize the ROS.

The methoxy and hydroxyl groups of the anti-oxidants with the highest reactivity can make free radicals inactive (i.e., Eq. (1)): 
Table 2 Validation of significant DEGs using DisGeNET and literature evidence for their related diseases. $\log _{2}|F C|$ values are derived from ExAtlas meta-analysis web server

\begin{tabular}{|c|c|c|c|}
\hline Gene Symbols & $\log _{2}|\mathrm{FC}|$ & DisGeNET & Literature \\
\hline \multirow[t]{3}{*}{ CTSL } & \multirow[t]{3}{*}{$1.47^{1}$} & $\begin{array}{l}\text { Disease: Meningioma } \\
\text { Disease Class: Neoplasms; Nervous System Diseases [79] }\end{array}$ & Skin Proteome and Degradome [80] \\
\hline & & $\begin{array}{l}\text { Disease: Liver carcinoma } \\
\text { Disease Class: Digestive System Diseases; Neoplasms [81] }\end{array}$ & Keratinocytes and perturbation of hair Follicle cycling [82] \\
\hline & & $\begin{array}{l}\text { Disease: Hereditary Diffuse Gastric Cancer } \\
\text { Disease Class: Digestive System Diseases; Neoplasms [83] }\end{array}$ & Mouse skin carcinogenesis [84] \\
\hline $\begin{array}{l}\text { RFPL4AL1 } \\
\text { *Paralog of FPL4A gene }\end{array}$ & $1.56^{1}$ & $\begin{array}{l}\text { Disease: Malignant neoplasms } \\
\text { Class: Neoplasms } \\
\text { Disease: Colorectal carcinoma } \\
\text { Class: Digestive System Diseases; Neoplasms } \\
\text { Disease: Primary malignant neoplasm } \\
\text { Class: Neoplasms [85] }\end{array}$ & $\begin{array}{l}\text { Malignant melanoma [86] } \\
\text { COVID-19 disease [87] } \\
\text { Hepatocellular carcinoma [88] }\end{array}$ \\
\hline \multirow[t]{3}{*}{ TNFRSF11B } & \multirow[t]{3}{*}{$1.62^{1}$} & $\begin{array}{l}\text { Disease: Hyperphosphatasemia with bone disease } \\
\text { Disease Class: Musculoskeletal Diseases [89] }\end{array}$ & Skin inflammation [90] \\
\hline & & $\begin{array}{l}\text { Disease: Osteoporosis } \\
\text { Disease Class: Nutritional and Metabolic Diseases; Musculo- } \\
\text { skeletal Diseases [91] }\end{array}$ & Skeletal dysplasias [92] \\
\hline & & $\begin{array}{l}\text { Disease: Rheumatoid Arthritis } \\
\text { Disease Class: Skin and Connective Tissue Diseases; Muscu- } \\
\text { loskeletal Diseases; Immune System Diseases [93] }\end{array}$ & \\
\hline SPACA5 & $1.64^{1}$ & No matches found & Bladder cancer [94] \\
\hline \multirow[t]{3}{*}{ TMEM158 } & \multirow[t]{3}{*}{$1.88^{1}$} & Disease: Neoplasms [95] & Pediatric localized scleroderma skin [96] \\
\hline & & $\begin{array}{l}\text { Disease: Carcinogenesis } \\
\text { Disease Class: Pathological Conditions, Signs, and Symp- } \\
\text { toms; Neoplasms [97] }\end{array}$ & $\begin{array}{l}\text { Anaplastic large cell lymphoma } \\
\text { [97] }\end{array}$ \\
\hline & & $\begin{array}{l}\text { Disease: Ovarian neoplasm } \\
\text { Disease Class: Neoplasms; Female Urogenital Diseases and } \\
\text { Pregnancy Complications; Endocrine System Diseases [98] }\end{array}$ & Skin [99] \\
\hline \multirow[t]{3}{*}{ DNLZ } & \multirow[t]{3}{*}{$1.93^{1}$} & Disease: Neoplasms [100] & Immune evasion[101] \\
\hline & & $\begin{array}{l}\text { Disease: Liver carcinoma } \\
\text { Disease Class: Digestive System Diseases; Neoplasms [102] }\end{array}$ & Fibrogenic responses [103] \\
\hline & & Disease: Tumor cell invasion [104] & Psoriasis [105] \\
\hline MIR614 & $2.00^{1}$ & $\begin{array}{l}\text { Disease: ovarian neoplasm; malignant neoplasm of ovary; } \\
\text { carcinoma, ovarian epithelial } \\
\text { Disease Class: Neoplasms; Female Urogenital Diseases and } \\
\text { Pregnancy Complications; Endocrine System Diseases [106] }\end{array}$ & $\begin{array}{l}\text { Psoriasis [107] } \\
\text { Suppression of stromal interferon signaling [108] }\end{array}$ \\
\hline MIR1282 & $2.00^{1}$ & No matches found & $\begin{array}{l}\text { Breast cancers [109] } \\
\text { Hepatocellular carcinoma [1 10] } \\
\text { Associated with immune organs and immunocytes [111] }\end{array}$ \\
\hline MIR4469 & $2.58^{1}$ & $\begin{array}{l}\text { Disease: Malignant neoplasm of breast; breast carcinoma } \\
\text { Disease Class: Neoplasms; Skin and Connective Tissue } \\
\text { Diseases [112] }\end{array}$ & $\begin{array}{l}\text { Atherosclerosis [113] } \\
\text { Laryngeal carcinoma cells [114] }\end{array}$ \\
\hline $\begin{array}{l}\text { LOC100287497 } \\
\text { (SEPTIN7P13) }\end{array}$ & $0.50^{2}$ & No matches found & $\begin{array}{l}\text { Hepatocellular carcinoma [114] } \\
\text { Urinary bladder cancer [115] }\end{array}$ \\
\hline ORgI1 & $0.59^{2}$ & No matches found & Human keratinocytes [116] \\
\hline CNNM3-DT & $0.60^{2}$ & $\begin{array}{l}\text { Disease: Rheumatoid arthritis } \\
\text { Disease Class: Skin and Connective Tissue Diseases; Muscu- } \\
\text { loskeletal Diseases; Immune System Diseases [117] }\end{array}$ & Lipid metabolism [118] \\
\hline \multirow[t]{3}{*}{ ENDOU } & \multirow[t]{3}{*}{$0.61^{2}$} & $\begin{array}{l}\text { Disease: Mental depression } \\
\text { Disease Class: Behavior Mechanisms [119] }\end{array}$ & Skin diseases [120] \\
\hline & & $\begin{array}{l}\text { Disease: Depressive disorder } \\
\text { Disease Class: Mental Disorders [121] }\end{array}$ & \\
\hline & & $\begin{array}{l}\text { Disease: Depressed mood } \\
\text { Disease Class: Behavior and Behavior Mechanisms [122] }\end{array}$ & \\
\hline
\end{tabular}

\footnotetext{
${ }^{1}$ Upregulated DEGs

${ }^{2}$ Downregulated DEGs
} 


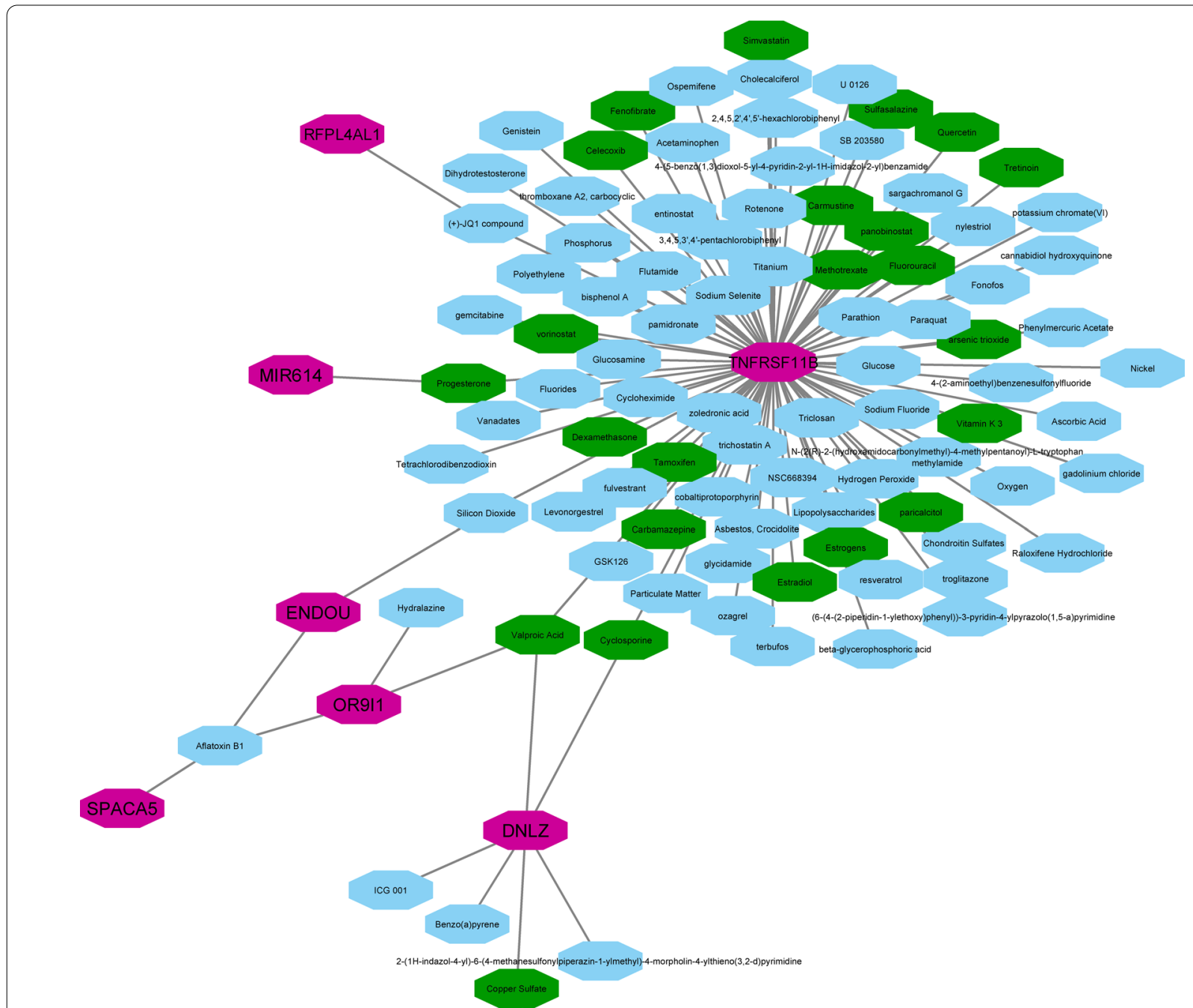

Fig. 4 The gene-chemicals association network illustrating compounds directly connected with chemicals for skin-related disorders in green color. The involved genes are shown in purple

Phenolic anti - oxidant $\left(\mathrm{OH}\right.$ or $\mathrm{OCH}_{3}$ or $\left.\ldots\right)+\mathrm{R}^{\cdot} \rightarrow$ Phenolic anti - oxidant $\left(\mathrm{O}\right.$ or $\mathrm{OCH}_{2}$ or ...) $+\mathrm{RH}$

where $\mathrm{R}^{\prime}$ is a type of free radical such as hydroxyl, peroxyl, alkoxyl, or alkyl radicals and $\mathrm{O}$ or $\mathrm{OCH}_{2}$ are the remained free radicals [46, 47]. Similarly, the mechanism of action of these chemicals, given their anti-inflammatory properties, applies through radical scavenging activities [48].

Additionally, it has been established that the immune system can function in the human body as a doubleedged sword in which immunity and immunopathology simultaneously provide benefits and do damage by balancing innate and adaptive immunity [49]. In a recent review, Zouboulis et al. stated that "In clinical practice, 'to look better' does not mean to 'look younger." [50].
Skin, the largest organ of the human body, inherits all immune system functions for better studying inflammation, autoimmunity, and cancer [51]. Skin aging is a multistep process that can be promoted through sun exposure, which may result in epidermal changes and photo-aging [52]. Various studies have proposed the benefits of natural compounds such as curcumin and its analogs in treating skin disorders such as skin aging [53, 54].

In the current investigation, the effects of Zingerone on epidermal tissues have been studied while considering the differentially expressed genes and the cellular components involved. As an outcome, without any exceptions, the assessed genes play roles in involving interleukins, 
Table 3 Structure activity relationships of similar compounds and their targets/enzymes

\begin{tabular}{|c|c|c|c|c|}
\hline \multirow[t]{2}{*}{ Compound } & \multirow[t]{2}{*}{ Structure } & \multirow[t]{2}{*}{ IC50 (nM) (BindingDB.org) } & \multicolumn{2}{|c|}{ Target/enzyme from DrugBank and literature } \\
\hline & & & Target & Enzyme \\
\hline Nabumetone & & $\begin{array}{l}>5.00 E+4 \\
\text { Estrogen receptor }\end{array}$ & $\begin{array}{l}\text { Prostaglandin G/H synthase } \\
2[123][124] \\
\text { Prostaglandin G/H synthase } \\
1[125,126]\end{array}$ & $\begin{array}{l}\text { Myeloperoxidase } \\
{[127]}\end{array}$ \\
\hline Masoprocol & & $\begin{array}{l}>5.00 E+4 \\
\text { Androgen receptor }\end{array}$ & $\begin{array}{l}\text { Arachidonate 5-lipoxyge- } \\
\text { nase [128] [129] } \\
\text { Sex hormone-binding } \\
\text { globulin [130] }\end{array}$ & $\begin{array}{l}\text { Arachidonate } \\
\text { 5-lipoxygenase } \\
\text { [131] }\end{array}$ \\
\hline Matairesinol & & $\begin{array}{l}5.20 \mathrm{E}+4 \\
\text { Testis-specific androgen- } \\
\text { binding protein }\end{array}$ & $\begin{array}{l}\text { Dehydrogenase/reductase } \\
\text { SDR family member 4-like } \\
2 \text { [132] }\end{array}$ & N/A \\
\hline $\begin{array}{l}\text { 3-(4-hydroxyphenyl)- } \\
\text { 1-(2,4,6-trihydroxyphenyl) } \\
\text { propan-1-one (Phloretin) }\end{array}$ & & $\begin{array}{l}1.67 \mathrm{E}+5 \\
\text { Topoisomerase I/II }\end{array}$ & $\begin{array}{l}\text { HTH-type transcriptional } \\
\text { regulator TtgR [132] }\end{array}$ & N/A \\
\hline
\end{tabular}


Table 3 (continued)

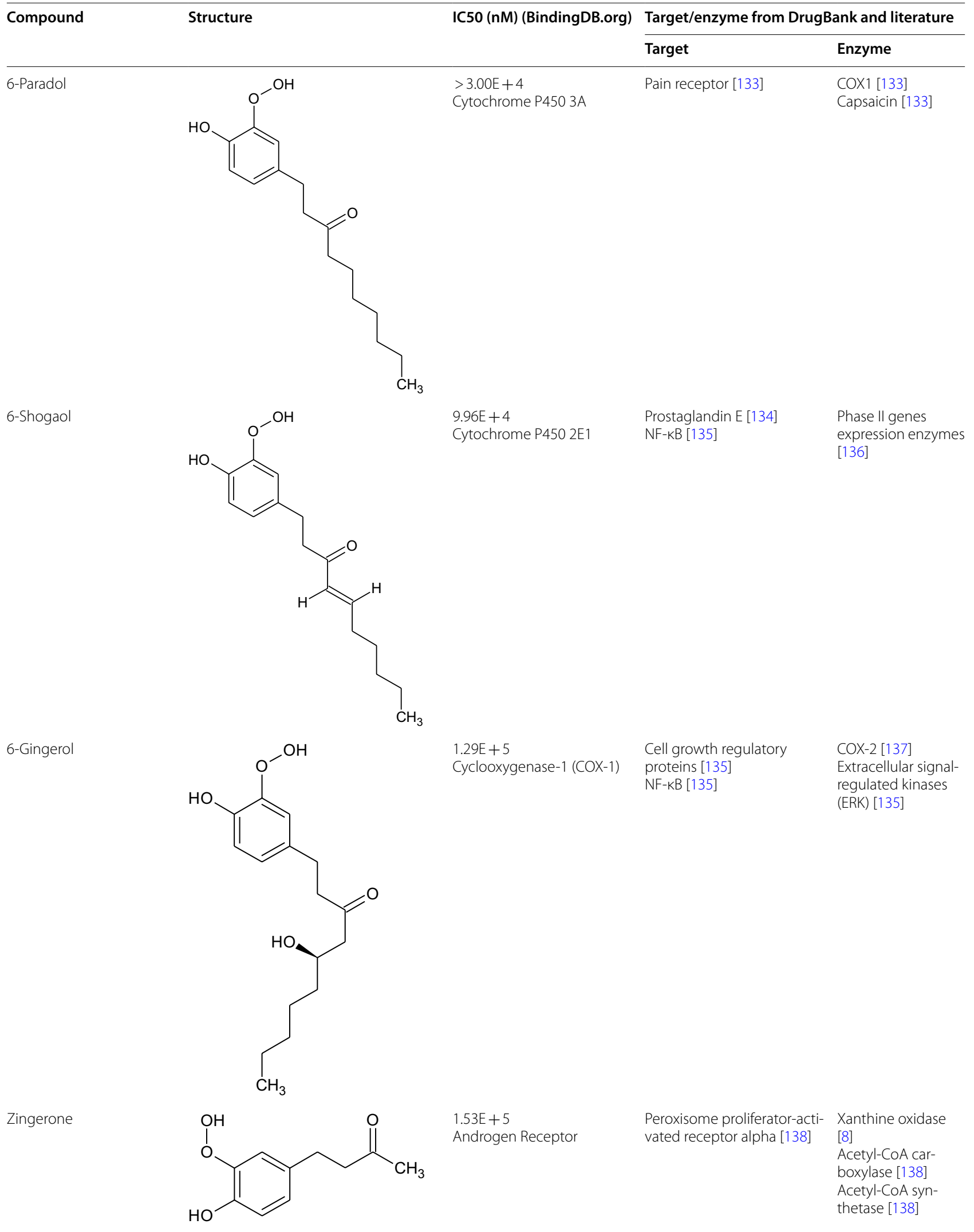


which are a well-known group of cytokines expressed mainly by leukocytes. Cytokines, which are produced by the Langerhans cells of the skin's immune system, were reported to play a significant role in skin aging [55]. Based on the identified differentially expressed genes and their effective cellular components in terms of GO, including GO:0005615 and GO:0005576, eighteen and four types of interleukins were determined to play roles in extracellular space and region, respectively.

In line with our results, Shirato et al. found that ETAS 50 could prevent skin aging by decreasing both UV-Binduced IL- 6 and IL-1 beta expressions $(56,57)$. Also, Guo et al. reported that adipose-derived stem cells could secrete several interleukins (e.g., interleukin-1 $\beta$, interleukin-8, interleukin-9, interleukin-12, interleukin-15, and interleukin-17) to inhibit skin aging [58]. Exercising could also affect interleukin-15 levels, thus preventing skin aging [59]. Interleukin 17 (or IL-17A) has a direct relationship with the stimulation of IL-23, making them a golden IL-23/IL-17 axis in age-associated inflammation and attenuates skin aging via acetyl Zingerone treatment through IL-17A stimulation [60, 61].

In summary, the current study proposed a hybrid systems biology and systems pharmacology procedure to identify the functional mechanisms and successful effects of Zingerone treatment. The proposed procedure considers the impact of similar compounds for stimulating the involved interleukins family on skin aging and their antioxidant and anti-inflammatory properties. More experimental studies on human and animal models are required to confirm the present results, as Zingerone's effects on cellular and molecular mechanisms on skin aging are still unclear.

\section{Conclusions}

The prominent role of herbal remedies is clear to the research and scientific communities. Skin aging and other types of skin disorders have attracted the attention of people throughout the world. In this regard, several drugs and chemicals have been proposed for anti-aging purposes. In this study, a computational and statistical procedure was considered to investigate the effect of Zingerone on skin aging at the cellular and genomic levels. Additionally, compounds that are structurally similar to Zingerone and their impacts on skin-related diseases were studied.

Furthermore, the gene-disease association and genechemicals network analyses revealed undeniable direct connections between genetics and skin disorders, including skin aging. Finally, various types of interleukins were found to have vital roles in attenuating skin aging. However, further research using human or animal models is required to confirm the effects of Zingerone determined in the present study.

\section{Abbreviations}

DEG: Differentially expressed genes; GEO: Gene expression omnibus; GO: Gene ontology; KEGG: Kyoto encyclopedia of genes and genomes; NCBI: National Center for Biotechnology Information; RHE: Reconstructed human epidermal; SMILES: Simplified Molecular Input Line Entry System; FDA: Food and Drug Administration (US); ADME: Absorption, distribution, metabolism, and excretion; CTSL: Cathepsin L; RFPL4AL1: Ret Finger Protein Like 4A Like 1; TNFRSF11B: TNF Receptor Superfamily Member 11b; SPACA5: Sperm Acrosome Associated 5; TMEM158: Transmembrane Protein 158; DNLZ: DNL-Type Zinc Finger; MIR614: MicroRNA 614; MIR1282: MicroRNA 1282; MIR4469: MicroRNA 4469; LOC100287497 (SEPTIN7P13): Septin 7 Pseudogene 13; OR911: Olfactory Receptor Family 9 Subfamily I Member 1; CNNM3-DT: CNNM3 Divergent Transcript; ENDOU: Endonuclease, Poly(U) Specific; UV: Ultraviolet radiation; ROS: Reactive oxygen species; NADPH: Nicotinamide adenine dinucleotide phosphate.

\section{Acknowledgements}

None.

\section{Authors' contributions}

BS and SA were involved in conceptualization and supervision; EA, BS, and SA helped in data curation, methodology, roles/writing —original draft and writing — review and editing; EA and SA — contributed to formal analysis; EA and BS were involved in investigation; BS - project administration; All authors read and approved the final manuscript.

\section{Funding}

None.

Availability of data and materials

Not applicable.

\section{Declarations}

Ethics approval and consent to participate

This article does not contain any studies with human participants or animals performed by any of the authors.

Consent for publication

Not applicable.

Competing interests

The authors declare that they have no competing interest.

Received: 26 April 2021 Accepted: 31 August 2021

Published online: 13 December 2021

\footnotetext{
References

1. Rosenthal A, Jacoby T, Israilevich R, Moy R (2019) The role of bioidentical hormone replacement therapy in anti-aging medicine: a review of the literature. Int J Dermatol. Online ahead of print

2. Bickers DR, Athar M (2006) Oxidative stress in the pathogenesis of skin disease. J Investig Dermatol 126(12):2565-2575

3. Sator PG (2006) Skin treatments and dermatological procedures to promote youthful skin. Clin Interv Aging 1(1):51

4. Dunaway S, Odin R, Zhou L, Ji L, Zhang Y, Kadekaro AL (2018) Natural antioxidants: multiple mechanisms to protect skin from solar radiation. Front Pharmacol 9:392

5. Choi J-S, Ryu J, Bae W-Y, Park A, Nam S, Kim J-E et al (2018) Zingerone suppresses tumor development through decreasing cyclin D1 expression and inducing mitotic arrest. Int J Mol Sci 19(9):2832

6. Kandemir FM, Yildirim S, Kucukler S, Caglayan C, Mahamadu A, Dortbudak MB (2018) Therapeutic efficacy of zingerone against
} 
vancomycin-induced oxidative stress, inflammation, apoptosis and aquaporin 1 permeability in rat kidney. Biomed Pharmacother 105:981-991

7. Mani V, Arivalagan S, Siddique Al, Namasivayam N (2016) Antioxidant and anti-inflammatory role of zingerone in ethanol-induced hepatotoxicity. Mol Cell Biochem 421(1-2):169-181

8. Ahmad B, Rehman MU, Amin I, Arif A, Rasool S, Bhat SA et al (2015) A review on pharmacological properties of zingerone (4-(4-Hydroxy-3methoxyphenyl)-2-butanone). Sci World J 2015:816364

9. Lee J, Oh SW, Shin SW, Lee K-W, Cho J-Y, Lee J (2018) Zingerone protects keratinocyte stem cells from UVB-induced damage. Chem Biol Interact 279:27-33

10. Rashid S, Wali AF, Rashid SM, Alsaffar RM, Ahmad A, Jan BL, et al (2021) Zingerone Targets status epilepticus by blocking hippocampal neurodegeneration via regulation of redox imbalance, inflammation and apoptosis. Pharmaceuticals (Basel) 14(2)

11. Mir B, Amin I, Rehman M, Razak R, Ali A, Baba O et al (2018) Chemoprotective potential of zingerone (vanillyl acetone) in cyclophosphamide-induced hepatic toxicity. Pharmacogn Mag 14(57):434-439

12. Amin I, Hussain I, Rehman MU, Mir BA, Ganaie SA, Ahmad SB et al (2021) Zingerone prevents lead-induced toxicity in liver and kidney tissues by regulating the oxidative damage in Wistar rats. J Food Biochem 45(3):e13241

13. Rehman MU, Rashid SM, Rasool S, Shakeel S, Ahmad B, Ahmad SB et al (2019) Zingerone (4-(4-hydroxy-3-methylphenyl)butan-2-one) ameliorates renal function via controlling oxidative burst and inflammation in experimental diabetic nephropathy. Arch Physiol Biochem 125(3):201-209

14. Bashir N, Ahmad SB, Rehman MU, Muzamil S, Bhat RR, Mir MUR et al (2021) Zingerone (4-(four-hydroxy-3-methylphenyl) butane-two-1) modulates adjuvant-induced rheumatoid arthritis by regulating inflammatory cytokines and antioxidants. Redox Rep Commun Free Radic Res 26(1):62-70

15. Wali AF, Rehman MU, Raish M, Kazi M, Rao PGM, Alnemer O, et al (2020) Zingerone [4-(3-methoxy-4-hydroxyphenyl)-butan-2] attenuates lipopolysaccharide-induced inflammation and protects rats from sepsis associated multi organ damage. Molecules 25(21)

16. Ganaie MA, Al Saeedan A, Madhkali H, Jan BL, Khatlani T, Sheikh IA et al (2019) Chemopreventive efficacy zingerone (4-[4-hydroxy3-methylphenyl] butan-2-one) in experimental colon carcinogenesis in Wistar rats. Environ Toxicol 34(5):610-625

17. Ahmad B, Rehman MU, Amin I, Mir MUR, Ahmad SB, Farooq A et al (2018) Zingerone (4-(4-hydroxy-3-methylphenyl) butan-2-one) protects against alloxan-induced diabetes via alleviation of oxidative stress and inflammation: probable role of NF-kB activation. Saudi Pharm J SPJ 26(8):1137-1145

18. Rehman MU, Ahmad B, Arif A, Rasool S, Farooq A, Razzaq R et al (2015) Zingerone protects against cisplatin-induced oxidative damage in the jejunum of Wistar rats. Orient Pharm Exp Med 15(3): 199-206

19. Carvalho B. pd.hugene.2.1.st: Platform Design Info for Affymetrix HuGene-2_1-st. R package version 3.14.1. https://www.bioconductor. org/ 2015:1-2

20. da Huang W, Sherman BT, Lempicki RA (2009) Systematic and integrative analysis of large gene lists using DAVID bioinformatics resources. Nat Protoc 4(1):44-57

21. da Huang W, Sherman BT, Lempicki RA (2009) Bioinformatics enrichment tools: paths toward the comprehensive functional analysis of large gene lists. Nucleic Acids Res 37(1):1-13

22. Kim S, Chen J, Cheng T, Gindulyte A, He J, He S et al (2021) PubChem in 2021: new data content and improved web interfaces. Nucleic Acids Res 49(D1):D1388-D1395

23. Daina A, Michielin O, Zoete V (2014) iLOGP: a simple, robust, and efficient description of n-octanol/water partition coefficient for drug design using the GB/SA approach. J Chem Inf Model 54(12):3284-3301

24. Daina A, Michielin O, Zoete V (2017) SwissADME: a free web tool to evaluate pharmacokinetics, drug-likeness and medicinal chemistry friendliness of small molecules. Sci Rep 7:42717

25. Daina A, Zoete V (2016) A boiled-egg to predict gastrointestinal absorption and brain penetration of small molecules. ChemMedChem 11(11):1117-1121
26. Zoete V, Daina A, Bovigny C, Michielin O (2016) SwissSimilarity: a web tool for low to ultra high throughput ligand-based virtual screening. J Chem Inf Model 56(8):1399-1404

27. Gfeller D, Michielin O, Zoete V (2013) Shaping the interaction landscape of bioactive molecules. Bioinformatics 29(23):3073-3079

28. Piñero J, Ramírez-Anguita JM, Saüch-Pitarch J, Ronzano F, Centeno E, Sanz F et al (2020) The DisGeNET knowledge platform for disease genomics: 2019 update. NAR 48(D1):D845-D855

29. Xia J, Gill EE, Hancock REW (2015) NetworkAnalyst for statistical, visual and network-based meta-analysis of gene expression data. Nat Protoc 10(6):823-844

30. Jallad KN (2017) Chemical characterization of sunscreens composition and its related potential adverse health effects. J Cosmet Dermatol 16(3):353-357

31. Ikehata H (2018) Mechanistic considerations on the wavelengthdependent variations of UVR genotoxicity and mutagenesis in skin: the discrimination of UVA-signature from UV-signature mutation. Photochem Photobiol Sci 17(12):1861-1871

32. Browne N, Donovan F, Murray P, Saha S (2014) Cyanobacteria as biofactories for production of UV-screening compounds. OA Biotechnol $3(6)$

33. Cadet J, Sage E, Douki T (2005) Ultraviolet radiation-mediated damage to cellular DNA. Mutat Res/Fundam Mol Mech Mutagen 571(1-2):3-17

34. Subedi L, Lee TH, Wahedi HM, Baek S-H, Kim SY (2017) Resveratrolenriched rice attenuates UVB-ROS-induced skin aging via downregulation of inflammatory cascades. Oxid Med Cell Longev. 2017

35. Valencia A, Kochevar IE (2008) Nox1-based NADPH oxidase is the major source of UVA-induced reactive oxygen species in human keratinocytes. J Investig Dermatol 128(1):214-222

36. Rhodes LE, Gledhill K, Masoodi M, Haylett AK, Brownrigg M, Thody AJ et al (2009) The sunburn response in human skin is characterized by sequential eicosanoid profiles that may mediate its early and late phases. FASEB J 23(11):3947-3956

37. Hwang K-A, Yi B-R, Choi K-C (2011) Molecular mechanisms and in vivo mouse models of skin aging associated with dermal matrix alterations. Lar 27(1):1-8

38. Scharffetter-Kochanek K, Wlaschek M, Briviba K, Sies H (1993) Singlet oxygen induces collagenase expression in human skin fibroblasts. FEBS Lett 331(3):304-306

39. Wlaschek M, Heinen G, Poswig A, Schwarz A, Krieg T, ScharffetterKochanek K (1994) UVA-induced autocrine stimulation of fibroblastderived collagenase/MMP-1 by interrelated loops of interleukin-1 and interleukin-6. Photochem Photobiol 59(5):550-556

40. Tanaka H, Okada T, Konishi H, Tsuji T (1993) The effect of reactive oxygen species on the biosynthesis of collagen and glycosaminoglycans in cultured human dermal fibroblasts. Arch Dermatol Res 285(6):352-355

41. Masaki H (2010) Role of antioxidants in the skin: anti-aging effects. J Dermatol Sci 58(2):85-90

42. Lee JY, Jang YW, Kang HS, Moon H, Sim SS, Kim CJ (2006) Anti-inflammatory action of phenolic compounds from Gastrodia elata root. Arch Pharm Res 29(10):849-858

43. Chen J, Yang J, Ma L, Li J, Shahzad N, Kim CK (2020) Structure-antioxidant activity relationship of methoxy, phenolic hydroxyl, and carboxylic acid groups of phenolic acids. Sci Rep 10(1):2611

44. Liu T, Lin Y, Wen X, Jorissen RN, Gilson MK (2007) BindingDB: a webaccessible database of experimentally determined protein-ligand binding affinities. NAR 35(suppl_1):D198-D201

45. Gilson MK, Liu T, Baitaluk M, Nicola G, Hwang L, Chong J (2016) BindingDB in 2015: a public database for medicinal chemistry, computational chemistry and systems pharmacology. NAR 44(D1):D1045-D1053

46. Krinsky NI (1992) Mechanism of action of biological antioxidants. PSEBM 200(2):248-254

47. Nijveldt RJ, Van Nood E, Van Hoorn DE, Boelens PG, Van Norren K, Van Leeuwen PA (2001) Flavonoids: a review of probable mechanisms of action and potential applications. Am J Clin Nutr 74(4):418-425

48. Hussain T, Tan B, Yin Y, Blachier F, Tossou MCB, Rahu N (2016) Oxidative stress and inflammation: What polyphenols can do for us? Oxid Med Cell Longev 2016:7432797

49. Musa M (2013) Immune mechanism: a "double-edged sword." Malays J Med Sci 20(3):61-67 
50. Zouboulis CC, Ganceviciene R, Liakou Al, Theodoridis A, Elewa R, Makrantonaki E (2019) Aesthetic aspects of skin aging, prevention, and local treatment. Clin Dermatol 37(4):365-372

51. Matejuk A (2018) Skin immunity. Arch Immunol Ther Exp 66(1):45-54

52. Bennett MF, Robinson MK, Baron ED, Cooper KD (2008) Skin immune systems and inflammation: protector of the skin or promoter of aging? J Investig Dermatol Proc 13(1):15-19

53. Panahi Y, Fazlolahzadeh O, Atkin SL, Majeed M, Butler AE, Johnston TP et al (2019) Evidence of curcumin and curcumin analogue effects in skin diseases: a narrative review. J Cell Physiol 234(2):1165-1178

54. Vollono L, Falconi M, Gaziano R, lacovelli F, Dika E, Terracciano C et al (2019) Potential of curcumin in skin disorders. Nutrients 11(9):2169

55. Borg M, Brincat S, Camilleri G, Schembri-Wismayer P, Brincat M, Calleja-Agius J (2013) The role of cytokines in skin aging. Climacteric 16(5):514-521

56. Shirato K, Koda T, Takanari J, Sakurai T, Ogasawara J, Imaizumi K et al (2018) Anti-inflammatory effect of ETAS ${ }^{\circledR} 50$ by inhibiting nuclear factor-kB p65 nuclear import in ultraviolet-B-irradiated normal human dermal fibroblasts. Evid Based Complement Altern Med 2018:5072986

57. Shirato K, Koda T, Takanari J, Ogasawara J, Sakurai T, Ohno H et al (2018) $\mathrm{ETAS}^{\circledR} 50$ attenuates ultraviolet-B-induced interleukin- 6 expression by suppressing Akt phosphorylation in normal human dermal fibroblasts. Evid Based Complement Altern Med 2018:1547120

58. Guo J, Pijun Y, Wang L, Shi Y, Liu Y, Chen W (2017) Research progress and application outlook of paracrine functions of adipose-derived stem cells in facial anti-aging. Chin J Tissue Eng Res 38(5):789-794

59. Crane JD, MacNeil LG, Lally JS, Ford RJ, Bujak AL, Brar IK et al (2015) Exercise-stimulated interleukin-15 is controlled by AMPK and regulates skin metabolism and aging. Aging Cell 14(4):625-634

60. Swindell WR, Bojanowski K, Chaudhuri RK (2019) A Zingerone Analog, Acetyl Zingerone, bolsters matrisome synthesis, inhibits matrix metallopeptidases, and represses IL-17A target gene expression. J Investig Dermatol 140(3):602-614

61. Mohammadi Shahrokhi V, Ravari A, Mirzaei T, Zare-Bidaki M, Asadikaram G, Arababadi MK (2018) IL-17A and IL-23: plausible risk factors to induce age-associated inflammation in Alzheimer's disease. Immunol Investig 47(8):812-822

62. Essawy SS (2011) Comparative study of the effect of allopurinol and nabumetone either alone or combined on Freund's adjuvant-induced arthritis in rats. Med J Cairo Univ 79(2)

63. Barth A, Kaiser N, Löffler U, Sourgens H, Klinger W (1994) Influence of the xanthine derivative denbufylline and the anti-inflammatory agent nabumetone on microsomal free radical production and lipid peroxidation in rat liver. Exp Toxicol Pathol 46(6):483-489

64. Jenner PN (1987) Nabumetone in the treatment of skin and soft tissue injury. Am J Med 83(4):101-106

65. Matsunami K (2018) Frailty and Caenorhabditis elegans as a benchtop animal model for screening drugs including natural herbs. Front Nutr 5:111

66. Olsen EA, Abernethy ML, Kulp-Shorten C, Callen JP, Glazer SD, Huntley A et al (1991) A double-blind, vehicle-controlled study evaluating masoprocol cream in the treatment of actinic keratoses on the head and neck. J Am Acad Dermatol 24(5):738-743

67. Yamauchi S, Sugahara T, Nakashima Y, Okada A, Akiyama K, Kishida T et al (2006) Radical and superoxide scavenging activities of matairesinol and oxidized matairesinol. Biosci Biotechnol Biochem 70(8):1934-1940

68. Xu P, Huang M-W, Xiao C-X, Long F, Wang Y, Liu S-Y et al (2017) Matairesinol suppresses neuroinflammation and migration associated with $\mathrm{SrC}$ and ERK1/2-NF-KB pathway in activating BV2 microglia. Neurochem Res 42(10):2850-2860

69. Kim M-J, Kim J-Y, Jung T-K, Choi S-W, Yoon K-S (2006) Skin anti-aging effect of Forsythia viridissima L. extract. KSBB J 21 (6):444-450

70. Behzad S, Sureda A, Barreca D, Nabavi SF, Rastrelli L, Nabavi SM (2017) Health effects of phloretin: from chemistry to medicine. Phytochem Rev 16(3):527-533

71. Oresajo C, Stephens T, Hino PD, Law RM, Yatskayer M, Foltis P et al (2008) Protective effects of a topical antioxidant mixture containing vitamin C, ferulic acid, and phloretin against ultraviolet-induced photodamage in human skin. J Cosmet Dermatol 7(4):290-297
72. Shin S, Kum H, Ryu D, Kim M, Jung E, Park D (2014) Protective effects of a new phloretin derivative against UVB-induced damage in skin cell model and human volunteers. Int J Mol Sci 15(10):18919-18940

73. Li F, Nitteranon V, Tang X, Liang J, Zhang G, Parkin KL et al (2012) In vitro antioxidant and anti-inflammatory activities of 1-dehydro-[6]-gingerdione, 6-shogaol, 6-dehydroshogaol and hexahydrocurcumin. Food Chem 135(2):332-337

74. Dugasani S, Pichika MR, Nadarajah VD, Balijepalli MK, Tandra S, Korlakunta JN (2010) Comparative antioxidant and anti-inflammatory effects of [6]-gingerol,[8]-gingerol,[10]-gingerol and [6]-shogaol. J Ethnopharmacol 127(2):515-520

75. Han HS, Kim KB, Jung JH, An IS, Kim Y-J, An S (2018) Anti-apoptotic, antioxidant and anti-aging effects of 6-shogaol on human dermal fibroblasts. Biomed Dermatol 2(1):1-8

76. Chung W-Y, Jung Y-J, Surh Y-J, Lee S-S, Park K-K (2001) Antioxidative and antitumor promoting effects of [6]-paradol and its homologs. Mutat Res/Genet Toxicol Environ Mutagen 496(1-2):199-206

77. Sapkota A, Park SJ, Choi JW (2019) Neuroprotective effects of 6-shogaol and its metabolite, 6-paradol, in a mouse model of multiple sclerosis. Biomol Ther (Seoul) 27(2):152

78. Kim J-K, Kim Y, Na K-M, Surh Y-J, Kim T-Y (2007) [6]-Gingerol prevents UVB-induced ROS production and COX-2 expression in vitro and in vivo. Free Rad Res 41(5):603-614

79. Lah TT, Nanni I, Trinkaus M, Metellus P, Dussert C, De Ridder L et al (2010) Toward understanding recurrent meningioma: the potential role of lysosomal cysteine proteases and their inhibitors. J Neurosurg 112(5):940-950

80. Tholen S, Biniossek ML, Gansz M, Gomez-Auli A, Bengsch F, Noel A et al (2013) Deletion of cysteine cathepsins B or $L$ yields differential impacts on murine skin proteome and degradome. Mol Cell Proteom 12(3):611-625

81. Ruan J, Zheng H, Fu W, Zhao P, Su N, Luo R (2014) Increased expression of cathepsin L: a novel independent prognostic marker of worse outcome in hepatocellular carcinoma patients. PLoS ONE 9(11):e112136

82. Roth W, Deussing J, Botchkarev VA, Pauly-Evers M, Saftig P, Hafner A et al (2000) Cathepsin L deficiency as molecular defect of furless: hyperproliferation of keratinocytes and pertubation of hair follicle cycling. FASEB J 14(13):2075-2086

83. Yamashita S, Tsujino Y, Moriguchi K, Tatematsu M, Ushijima T (2006) Chemical genomic screening for methylation-silenced genes in gastric cancer cell lines using 5-aza-2'-deoxycytidine treatment and oligonucleotide microarray. Cancer Sci 97(1):64-71

84. Benavides F, Perez C, Blando J, Contreras O, Shen J, Coussens LM et al (2012) Protective role of cathepsin L in mouse skin carcinogenesis. Mol Carcinog 51(4):352-361

85. Naito A, Yamamoto H, Kagawa Y, Naito Y, Okuzaki D, Otani K et al (2015) RFPL4A increases the G1 population and decreases sensitivity to chemotherapy in human colorectal cancer cells. J Biol Chem 290(10):6326-6337

86. Gil J, Kim Y, Szeitz B, Doma V, Çakır U, de Almeida NP, et al (2021) Proteogenomics reveals how metastatic melanoma modulates the immune system to allow immune evasion. bioRxiv. 2021:2021.04.10.439245

87. Hunter E, Koutsothanasi C, Wilson A, Santos FC, Salter M, Westra JW, et al (2020) Development and validation of blood-based prognostic biomarkers for severity of COVID disease outcome using EpiSwitch 3D genomic regulatory immuno-genetic profiling. medRxiv. 2021:2021.06.21.21259145

88. Hu Z, Huang P, Yan Y, Zhou Z, Wang J, Wu G (2019) Hepatitis B virus X protein related IncRNA WEE2-AS1 promotes hepatocellular carcinoma proliferation and invasion. Biochem Biophys Res Commun 508(1):79-86

89. Naot D, Wilson LC, Allgrove J, Adviento E, Piec I, Musson DS et al (2020) Juvenile Paget's disease with compound heterozygous mutations in TNFRSF11B presenting with recurrent clavicular fractures and a mild skeletal phenotype. Bone 130:115098

90. Laggner M, Copic D, Nemec L, Vorstandlechner V, Gugerell A, Gruber F et al (2020) Therapeutic potential of lipids obtained from $y$-irradiated PBMCs in dendritic cell-mediated skin inflammation. EBioMedicine 55:102774

91. Fallahnezhad S, Jajarmi V, Shahnavaz S, Amini A, Ghoreishi SK, Kazemi M et al (2020) Improvement in viability and mineralization of osteoporotic bone marrow mesenchymal stem cell through combined application 
of photobiomodulation therapy and oxytocin. Lasers Med Sci 35(3):557-566

92. Hellemans J (2007) Identification and analysis of genes involved in skeletal dysplasias affecting growth and bone homeostasis. Ghent University

93. Chen Y, Li H, Luo X, Liu H, Zhong Y, Wu X et al (2019) Moxibustion of Zusanli (ST36) and Shenshu (BL23) alleviates cartilage degradation through RANKL/OPG signaling in a rabbit model of rheumatoid arthritis. Evid Based Complement Altern Med 2019:6436420

94. Zhang XY, Yan QX, Guo XY, Chen CR, Chen RQ, Cai ZM et al (2016) Expression profile of SPACA5/Spaca5 in spermatogenesis and transitional cell carcinoma of the bladder. Oncol Lett 12(5):3731-3738

95. Fu Y, Yao N, Ding D, Zhang X, Liu H, Ma L et al (2020) TMEM158 promotes pancreatic cancer aggressiveness by activation of TGF $\beta 1$ and PI3K/AKT signaling pathway. J Cell Physiol 235(3):2761-2775

96. Mirizio E, Liu C, Yan Q, Waltermire J, Mandel R, Schollaert KL et al (2021) Genetic signatures from RNA sequencing of pediatric localized scleroderma skin. Front Pediatr 9:669116

97. Liu L, Zhang J, Li S, Yin L, Tai J (2020) Silencing of TMEM158 inhibits tumorigenesis and multidrug resistance in colorectal cancer. Nutr Cancer 72(4):662-671

98. Cheng Z, Guo J, Chen L, Luo N, Yang W, Qu X (2015) Overexpression of TMEM158 contributes to ovarian carcinogenesis. J Exp Clin Cancer Res 34(1):75

99. Lulli D, Carbone ML, Pastore S (2016) Epidermal growth factor receptor inhibitors trigger a type I interferon response in human skin. Oncotarget 7(30):47777-47793

100. Vezenkov LT, Tsekova DS, Kostadinova I, Mihaylova R, Vassilev NG, Danchev ND (2019) Synthesis of new galanthamine-peptide derivatives designed for prevention and treatment of Alzheimer's disease. Curr Alzheimer Res 16(3):183-192

101. Boyd A, Bennuru S, Wang Y, Sanprasert V, Law M, Chaussabel D et al (2013) Quiescent innate response to infective filariae by human Langerhans cells suggests a strategy of immune evasion. Infect Immun 81(5):1420-1429

102. He L, Cai X, Cheng S, Zhou H, Zhang Z, Ren J et al (2019) Ornithine transcarbamylase downregulation is associated with poor prognosis in hepatocellular carcinoma. Oncol Lett 17(6):5030-5038

103. Fang F, Shangguan AJ, Kelly K, Wei J, Gruner K, Ye B et al (2013) Early growth response 3 (Egr-3) is induced by transforming growth factor- $\beta$ and regulates fibrogenic responses. Am J Pathol 183(4):1197-1208

104. Ju A, Cho YC, Kim BR, Lee S, Le HTT, Vuong HL et al (2018) Anticancer effects of methanol extract of Myrmecodia platytyrea Becc. leaves against human hepatocellular carcinoma cells via inhibition of ERK and STAT3 signaling pathways. Int J Oncol 52(1):201-210

105. Müller A (2020) The Central Role of the Transcriptional Regulator I [kappa] B [zeta] in Psoriasis: Eberhard Karls Universität Tübingen

106. Zhang J, Gao D, Zhang H (2018) Upregulation of miR-614 promotes proliferation and inhibits apoptosis in ovarian cancer by suppressing PPP2R2A expression. Mol Med Rep 17(5):6285-6292

107. Ekman AK, Vegfors J, Eding CB, Enerbäck C (2017) Overexpression of Psoriasin (S100A7) contributes to dysregulated differentiation in psoriasis. Acta Derm Venereol 97(4):441-448

108. Raikhy G, Woodby BL, Scott ML, Shin G, Myers JE, Scott RS, et al (2019) Suppression of stromal interferon signaling by human papillomavirus 16. J Virol 93(19)

109. Qian P, Banerjee A, Wu ZS, Zhang X, Wang H, Pandey V et al (2012) Loss of SNAIL regulated miR-128-2 on chromosome 3p22.3 targets multiple stem cell factors to promote transformation of mammary epithelial cells. Cancer Res 72(22):6036-6050

110. Zhuang L, Xu L, Wang P, Meng Z (2015) Serum miR-128-2 serves as a prognostic marker for patients with hepatocellular carcinoma. PLoS ONE 10(2):e0117274

111. Yang $Y, X u J$ J, Chen $H$, Fei $X$, Tang $Y$, Yan $Y$ et al (2016) MiR-128-2 inhibits common lymphoid progenitors from developing into progenitor $B$ cells. Oncotarget 7(14):17520-17531

112. Cao T, Xiao T, Huang G, Xu Y, Zhu JJ, Wang K et al (2017) CDK3, target of miR-4469, suppresses breast cancer metastasis via inhibiting Wnt/ $\beta$ catenin pathway. Oncotarget 8(49):84917-84927

113. Sleptsov AA, Nazarenko MS, Lebedev IN, Skriabin NA, Frolov AV, Popov VA et al (2014) Somatic genome variations in vascular tissues and peripheral blood leukocytes in patients with atherosclerosis. Genetika 50(8):986-995

114. Xue HX, Li HF, Wang T, Li WJ, Bian WC (2020) LncRNA HCG11 suppresses laryngeal carcinoma cells progression via sponging miR-4469/APOM axis. Eur Rev Med Pharmacol Sci 24(6):3174-3182

115. Nascimento e Pontes MG, da Silveira SM, Trindade Filho JC, Rogatto SR, Viana de Camargo JL (2013) Chromosomal imbalances in successive moments of human bladder urothelial carcinoma. Urol Oncol 31(6):827-35

116. Kang W, Son B, Park S, Choi D, Park T (2021) UV-irradiation- and inflammation-induced skin barrier dysfunction is associated with the expression of olfactory receptor genes in human keratinocytes. Int J Mol Sci 22(6)

117. Lu MC, Yu HC, Yu CL, Huang HB, Koo M, Tung CH et al (2016) Increased expression of long noncoding RNAs LOC100652951 and LOC100506036 in T cells from patients with rheumatoid arthritis facilitates the inflammatory responses. Immunol Res 64(2):576-583

118. Muret K, Désert C, Lagoutte L, Boutin M, Gondret F, Zerjal T et al (2019) Long noncoding RNAs in lipid metabolism: literature review and conservation analysis across species. BMC Genom 20(1):882

119. Liu G, Wang Y, Zheng W, Cheng H, Zhou R (2019) P11 loss-of-function is associated with decreased cell proliferation and neurobehavioral disorders in mice. Int J Biol Sci 15(7):1383-1395

120. Edqvist PH, Fagerberg L, Hallström BM, Danielsson A, Edlund K, Uhlén M et al (2015) Expression of human skin-specific genes defined by transcriptomics and antibody-based profiling. J Histochem Cytochem 63(2):129-141

121. Gandhi M, Bhatt P, Chauhan G, Gupta S, Misra A, Mashru R (2019) IGFII-conjugated nanocarrier for brain-targeted delivery of p1 1 gene for depression. AAPS PharmSciTech 20(2):50

122. van Calker D, Serchov T, Normann C, Biber K (2018) Recent insights into antidepressant therapy: distinct pathways and potential common mechanisms in the treatment of depressive syndromes. Neurosci Biobehav Rev 88:63-72

123. Fackovcova D, Kristova V, Kriska M (2000) Renal damage induced by the treatment with non-opioid analgesics-theoretical assumption or clinical significance. Bratisl Lek Listy 101(8):417-422

124. Roy HK, Karolski WJ, Ratashak A (2001) Distal bowel selectivity in the chemoprevention of experimental colon carcinogenesis by the non-steroidal anti-inflammatory drug nabumetone. Int J Cancer 92(4):609-615

125. Giuliano F, Ferraz JG, Pereira R, de Nucci G, Warner TD (2001) Cyclooxygenase selectivity of non-steroid anti-inflammatory drugs in humans: ex vivo evaluation. Eur J Pharmacol 426(1-2):95-103

126. Takeuchi K, Smale S, Premchand P, Maiden L, Sherwood R, Thjodleifsson B et al (2006) Prevalence and mechanism of nonsteroidal anti-inflammatory drug-induced clinical relapse in patients with inflammatory bowel disease. Clin Gastroenterol Hepatol 4(2):196-202

127. Saleh TS, Calixto JB, Medeiros YS (1999) Effects of anti-inflammatory drugs upon nitrate and myeloperoxidase levels in the mouse pleurisy induced by carrageenan. Peptides 20(8):949-956

128. Audouin C, Mestdagh N, Lassoie MA, Houssin R, Hénichart JP (2001) $\mathrm{N}$-Aminoindoline derivatives as inhibitors of 5-lipoxygenase. Bioorg Med Chem Lett 11(6):845-848

129. Lambert JD, Meyers RO, Timmermann BN, Dorr RT (2001) Pharmacokinetic analysis by high-performance liquid chromatography of intravenous nordihydroguaiaretic acid in the mouse. J Chromatogr B Biomed Sci Appl 754(1):85-90

130. Hong H, Branham WS, Ng HW, Moland CL, Dial SL, Fang H et al (2015) Human sex hormone-binding globulin binding affinities of 125 structurally diverse chemicals and comparison with their binding to androgen receptor, estrogen receptor, and a-fetoprotein. Toxicol Sci 143(2):333-348

131. Wang B, Yu SC, Jiang JY, Porter GW, Zhao LT, Wang Z et al (2011) An inhibitor of arachidonate 5-lipoxygenase, Nordy, induces differentiation and inhibits self-renewal of glioma stem-like cells. Stem Cell Rev Rep 7(2):458-470

132. Berman HM, Westbrook J, Feng Z, Gilliland G, Bhat TN, Weissig H et al (2000) The protein data bank. Nucleic Acids Res 28(1):235-242 
133. Fajrin FA, Rahmayanti F, Pratoko DK. The binding prediction of 6-paradol and its derivatives on TRPV1 agonist as a new compound for treating painful diabetic neuropathy. Journal ILMU DASAR. 2020(2):133-8\%V 21

134. Eren D, Betul YM (2016) Revealing the effect of 6-gingerol, 6-shogaol and curcumin on mPGES-1, GSK-3 $\beta$ and $\beta$-catenin pathway in A549 cell line. Chem Biol Interact 258:257-265

135. Prasad S, Tyagi AK (2015) Ginger and its constituents: role in prevention and treatment of gastrointestinal cancer. Gastroenterol Res Pract 2015:142

136. Peng S, Yao J, Liu Y, Duan D, Zhang X, Fang J (2015) Activation of Nrf2 target enzymes conferring protection against oxidative stress in PC12 cells by ginger principal constituent 6-shogaol. Food Funct 6(8):2813-2823
137. Kim SO, Kundu JK, Shin YK, Park JH, Cho MH, Kim TY et al (2005) [6]-Gingerol inhibits COX-2 expression by blocking the activation of p38 MAP kinase and NF-kappaB in phorbol ester-stimulated mouse skin Oncogene 24(15):2558-2567

138. Geng X, Liu H, Yuwen Q, Wang J, Zhang S, Zhang X, et al. Protective effects of zingerone on high cholesterol diet-induced atherosclerosis through lipid regulatory signaling pathway. Human \& experimental toxicology. 2021:9603271211006170

\section{Publisher's Note}

Springer Nature remains neutral with regard to jurisdictional claims in published maps and institutional affiliations.

\section{Submit your manuscript to a SpringerOpen ${ }^{\circ}$ journal and benefit from:}

- Convenient online submission

- Rigorous peer review

- Open access: articles freely available online

- High visibility within the field

- Retaining the copyright to your article

Submit your next manuscript at $\boldsymbol{\nabla}$ springeropen.com 